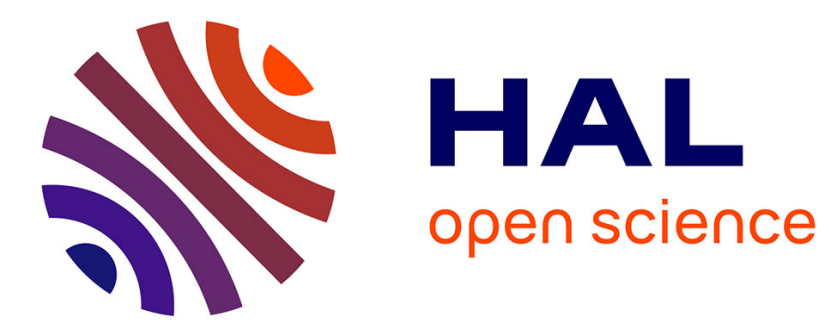

\title{
Predictive processing, perceptual presence, and sensorimotor theory
}

J. Kevin O'Regan, Jan Degenaar

\section{To cite this version:}

J. Kevin O'Regan, Jan Degenaar. Predictive processing, perceptual presence, and sensorimotor theory. Cognitive Neuroscience, 2013, 5 (2), pp.130-131. 10.1080/17588928.2014.907256 . hal-02314600

\section{HAL Id: hal-02314600 \\ https://hal-univ-paris.archives-ouvertes.fr/hal-02314600}

Submitted on 12 Oct 2019

HAL is a multi-disciplinary open access archive for the deposit and dissemination of scientific research documents, whether they are published or not. The documents may come from teaching and research institutions in France or abroad, or from public or private research centers.
L'archive ouverte pluridisciplinaire HAL, est destinée au dépôt et à la diffusion de documents scientifiques de niveau recherche, publiés ou non, émanant des établissements d'enseignement et de recherche français ou étrangers, des laboratoires publics ou privés. 
Published in Cognitive Neuroscience, doi 10.1080/17588928.2014.907256

\title{
Predictive processing, perceptual presence, and sensorimotor theory
}

\author{
J. Kevin O’Regan \& Jan Degenaar
}

Abstract

Mastery of sensorimotor contingencies can be viewed as attunement to potentialities. In our view, these potentialities have wider application than recognized in Seth's account of sensory presence, and should pertain to all of sensory experience. Instead of appealing only to a notion of counterfactual richness, we propose that the degree of sensory presence can be further specified in terms of bodiliness, insubordinateness, and grabbiness. While PPSMC can provide a possible implementation of a sensorimotor account of synesthesia, we suggest it should be rid of its representationalist interpretation.

Seth's PPSMC theory offers an interesting hypothesis on the neural processes involved in the mastery of sensorimotor contingencies. Importantly, Seth and we agree that this mastery, which guarantees the feel of really perceiving, must involve being attuned to (or having implicit knowledge of) not just actual, but additionally, potential sensorimotor contingencies. It is this attunement to potentiality which in Seth's account corresponds to access to 
counterfactuals, and which in our sensorimotor approach corresponds partly to what we call “mastery" of sensorimotor contingencies.

But it would seem that Seth's appeal to counterfactuals is exclusively used in an account of sensory presence, whereas in the sensorimotor theory, counterfactuals (or more precisely, potential sensorimotor contingencies) are necessarily involved in all perceptual experience. For example, under the sensorimotor theory, to perceive a patch as red is to be attuned to the retinal changes that would occur if one were to move the patch around under different illuminations (cf. O'Regan, 2011 O'Regan, J. K. (2011). Why red doesn't sound like a bell: Understanding the feel of consciousness. New York, NY: Oxford University Press; Philipona \& O’Regan, 2006Philipona, D. L., \& O’Regan, J. K.(2006). Color naming, unique hues, and hue cancellation predicted from singularities in reflection properties. Visual Neuroscience, 23(3-4), 331-339. doi:10.1017/S0952523806233182; Vazquez-Corral, O’Regan, Vanrell, \& Finlayson, 2012Vazquez-Corral, J., O’Regan, J. K., Vanrell, M., \& Finlayson, G. D.(2012). A new spectrally sharpened sensor basis to predict color naming, unique hues, and hue cancellation. Journal of Vision, 12(6). doi:10.1167/12.6.7_). Thus, our claim would be that the experience of concurrent redness in synesthesia would also require counterfactual sensorimotor contingencies of red to hold: Otherwise there would be no experience of red.

To account for the lesser perceptual presence of concurrent experiences in synesthesia, Seth appeals to lesser counterfactual richness. But to pinpoint what causes perceptual presence or its lack, we would go further than appealing to the degree of richness. The experienced sensory presence or phenomenality of sensory experience is governed by three particular characteristics of sensorimotor contingencies, namely what we call bodiliness, insubordinateness, and grabbiness (e.g., O'Regan, 2011O'Regan, J. K. (2011). Why red doesn't sound like a bell: Understanding the feel of consciousness. New York, NY: Oxford University Press; O’Regan, Myin, \& Noë, 2005a,b O’Regan, J. K., Myin, E., 
\& Noë, A.(2005b). Sensory consciousness explained (better) in terms of 'corporality' and 'alerting capacity'. Phenomenology and the Cognitive Sciences, 4(4), 369-387. doi:10.1007/s11097-005-9000-0). These are objective facts about sensorimotor contingencies that guarantee that they actually correspond to real-world interactions. Using bodiliness, insubordinateness, and grabbiness, we can begin to make a classification that predicts the degree of sensory presence, going from thinking and memory, through imagining, dreaming, emotions, pain, and socially determined states like pride and embarrassment, and including visceral states, proprioception, and vestibular processes, up to sensations provided by the five classic sense modalities of seeing, hearing, touching, smelling, and tasting - these latter being those that are considered as having the highest degree of properly sensory presence.

Bodiliness, insubordinateness, and grabbiness provide greater leverage in comparing and contrasting degrees of perceptual presence than appealing to the generic notion of richness of counterfactuals. For example, these concepts help to explain why visceral sensory systems, proprioception, and the vestibular sense, do not have obvious sensory presence, even though they presumably involve brain systems with hierarchical global models and predictive processing just like the five classic senses. We suspect that PPSMC's explanation would be more ad hoc.

Another comment concerns how the sensorimotor account and PPSMC deal with synesthesia. In our view, sensorimotor theory itself already has the resources to explain synesthesia and its resistance to adaptation. The fact that, as Seth notes, the experience of a synesthetic concurrent "seems to have little to do with the SMCs underwriting the perception of the inducer," presents no more of a challenge to sensorimotor theory than the fact that we can vividly imagine things that are absent. Once one has mastery over the sensorimotor dependencies of red, the experience of red can potentially be evoked in an atypical way. Perhaps because the relevant cortical activity is "dangling" semi-independently of the present 
sensorimotor engagement (Hurley \& Noë, 2003Hurley, S., \& Noë, A. (2003). Neural plasticity and consciousness. Biology and Philosophy, 18(1), 131-168.

doi:10.1023/A:1023308401356), or because of other (possibly genetic) factors counteracting neural plasticity, synesthesia may then not adapt away through interaction with the environment.

PPSMC essentially provides a possible neural implementation of these ideas. It proposes that synesthesia may have something to do with "intermediate level generative models," speculating that these "are endowed with unusually high prior precision weighting so that these priors overwhelm concurrent-related sensory prediction errors flowing from lower levels." This may be one way to be "dangling" or to otherwise counteract plasticity. Of course, whether this way is in fact instantiated in synesthetes requires neuroscientific evidence, and Seth's account does the service that it may help to look for such evidence.

A final comment concerns the notion of representation in the PPSMC model. While Seth speaks of representational models of external causes, we would reject such a representational interpretation. We have no objection to saying that from the scientist's outside perspective there may exist brain processes that can be viewed as hierarchically organized, with one layer functioning as if it "predicts" the activity of a lower layer. But this should not be taken to say that the higher levels represent external causes.

This work was supported by ERC Advanced grant [323674] "FEEL" to J. Kevin O'Regan.

\section{REFERENCES}

1. Hurley, S., \& Noë, A. (2003). Neural plasticity and consciousness. Biology and Philosophy, 18(1), 131-168. doi:10.1023/A:1023308401356 
2. O'Regan, J. K. (2011). Why red doesn't sound like a bell: Understanding the feel of

3. O'Regan, J. K., Myin, E., \& Noë, A. (2005a). Skill, corporality and alerting capacity in an account of sensory consciousness. Progress in Brain Research, 150, 55-68.

4. O’Regan, J. K., Myin, E., \& Noë, A. (2005b). Sensory consciousness explained (better) in terms of 'corporality' and 'alerting capacity'. Phenomenology and the Cognitive Sciences,

5. Philipona, D. L., \& O’Regan, J. K. (2006). Color naming, unique hues, and hue cancellation predicted from singularities in reflection properties. Visual Neuroscience, 23(3-4), 331-339. doi:10.1017/S0952523806233182

6. Vazquez-Corral, J., O’Regan, J. K., Vanrell, M., \& Finlayson, G. D. (2012). A new spectrally sharpened sensor basis to predict color naming, unique hues, and hue cancellation. Journal of Vision, 12(6). doi:10.1167/12.6.7 